\title{
Participatory Mapping and SWOT in the context of the Water-Food-Energy Nexus for attaining SDGs in Eastern Amazonia
}

\author{
Gislleidy Uchôa Tavares a ${ }^{\text {a }}$ Regina Balbino da Silva ${ }^{\text {a }}$, Thomaz Willian de Figueiredo Xavier ${ }^{\text {a }}$ \\ Adryane Gorayeb $^{\mathrm{a} *}$, Christian Brannstrom ${ }^{\mathrm{b}}$ \\ ${ }^{a}$ Federal University of Ceará(UFC),gislleidyuchoa@hotmail.com,reginabalbino2011@gmail.com,txavier@alu.ufc.br, \\ gorayeb@ufc.br \\ ${ }^{b}$ Texas A\&M University, cbrannst@geos.tamu.edu \\ * Corresponding author
}

\begin{abstract}
The nexus concept is applied to many global contexts to generate understanding of the relations among the water, food and energy sectors and to guide investigations that seek to improve living conditions of marginalized communities. This work analyses the nexus by means of qualitative and participative methodologies at a community scale with the objective of understanding how residents of traditional communities perceive the interconnections among water, food, and energy. SWOT and participatory mapping methodologies were utilized complementarily to map the water, food, and energy contexts of Ponta do Urumajó community, located in Pará state, Brazil. Participatory mapping and SWOT create quali-quantitative data, enabling the participation of individuals in the production of participatory maps of their territories and the material and symbolic appropriation of spaces, constituting a political and social strategy for empowerment and autonomy. These methods provided the basis for learning and reflecting on the social, environmental, territorial, and political reality in terms of the water, food, and energy nexus, making it possible to use the data for achieving the SDGs, creating future public policies or more rational community management adjusted to the local reality.
\end{abstract}

Keywords: Nexus, SWOT Matrix, Participatory Mapping, Traditional Communities, Brazil.

\section{Introduction}

Nexus defines a connection or link between two or more elements, circumstances or occurrences (Kalberg et al., 2015; Leck et al., 2015). Nexus thinking is an approach that can be used for achieving sustainable development and that should focus on social justice, political-economic development and environmental conservation. According to Melloni et al. (2020, p. 1-2), assessment of the WaterEnergy-Food (WEF) nexus "supports natural resource management by providing an integrated framework for evaluation and decision-making."

The research on the WEF nexus mainly deploys quantitative top-down methodologies, at a national scale, with few examples of participative and collaborative approaches (Albrecht, Crootof and Scott 2018; Mercure et al. 2019; Dalla Fontana et al. 2020; Daher et al. 2019). However, authors such as Leal et al. (2018), Kraftl et al. (2019), Melloni et al. (2020) and Kalberg et al. (2015) argue for nexus-related studies to be built from bottom-up approaches, utilizing qualitative, participative and collaborative methodologies in which the key actors participate in the nexus analysis and become principal agents in the decision-making process.

This work also focuses on attaining the Sustainable Development Goals (SDGs), notably in relation to SDGs $1,2,6,7,8,15$ and 17, which focus respectively on poverty, hunger, water and sanitation, sustainable energy, employment, ecosystem protection/biodiversity, and, in partnerships in favour of other Agenda 2030 goals of the
United Nations (UN), which consider water, energy and food security at the community scale.

According to Dalla Fontana (2020), nexus studies in the Brazil's northern region (Amazonia) are lacking. Thus, this work applies qualitative and participatory methodologies in order to understand and analyze the nexus in the Brazilian northern region, more precisely in the community of Ponta do Urumajó, located in the municipality of Augusto Corrêa, in the state of Pará (Figure 1). Ponta do Urumajó is located $8.1 \mathrm{~km}$ from the municipality of Augusto Corrêa, lower course of the Caeté River in eastern Amazonia. According to Freitas et al. (2017), 110 families reside in the community and a large part of their income comes from farming activities, clamming, fishing, small animal husbandry and from federal income distribution programs, especially Bolsa Família.

The objective of this work is to understand the WEF nexus holistically, that is, in an integrated and participatory manner, by means of bottom-up approaches, using participatory mapping and the SWOT matrix. Participatory Mapping or Social Cartography ("cartografia social" as it is known in Brazil) is a tool that allows communities to map their territories and fight for their interests, pursuing their rights and satisfaction of their needs (Gorayeb, 2014). The SWOT matrix is a diagnostic methodology suited to various contexts, in focus groups or workshops, and effective for gathering opinions and stimulating discussions. 
The aim of combining the two methodologies in this study is to utilize a participatory bottom-up approach. The methodologies are applied complementarily: one generates discussion and gathers data by means of a socioenvironmental diagnosis and the other maps the data collected within the context of the water-food-energy nexus. Applying the SWOT matrix to the nexus is incipient, especially associated to participatory mapping.

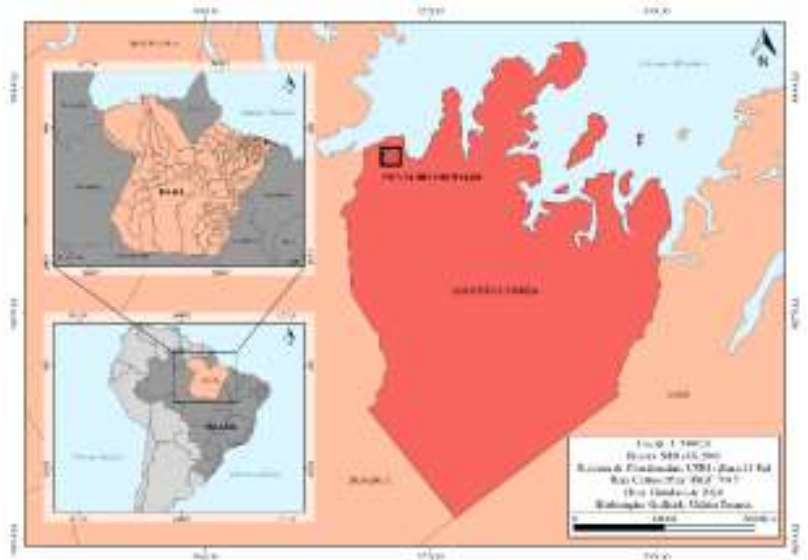

Figure 1. Location Map of the Ponta do Urumajó Community, Augusto Corrêa, Pará, Brazil.

\subsection{SWOT Matrix Spatialization: Participatory Mapping from Water, Food and Energy Security}

Maps, formerly made only by qualified professionals and utilized as a form of power, are beginning to be prepared by the general population where everyone is free to create and use the collaborative maps, which are in continuous construction. Mapping that involves local populations has the "objective of producing interpretations of the social, economic and ecological issues, taking into consideration the experience of the social actors involved" (Acselrad; Coli, 2008, p.33). Participatory mapping allows the community to decide how the map will be composed, in a process of empowerment and autonomy to represent its knowledge in relation to the space, the environment and the culture of the local populations. It is important that social cartography be carried out by the community and that the researchers only be the mediators for the production of the map, for the map is also a political instrument of the community itself and must have the integrity to be a document for territorial integrity.

Thus, social cartography has the purpose of giving underprivileged communities and groups a voice. Social mapping actions can be linked to identity and territorialization, as well as to rational natural resource management, such as access to water, for example, in addition to showing socio-territorial and environmental conflicts (Acselrad et al., 2010).

Social cartography allows actions on various fronts in terms of planning because it results from a collective analysis of the space and the actors who are inserted therein. Gorayeb, Meireles and Silva, (2015, p.18), emphasize that "the attitude of mapping actions, objects and processes results in a greater group reflection on daily life and its praxis, permitting the exercise of community attitudes."

The products generated by participatory mapping result from a united vision of these actors, who in expressing these characteristics, present a closer approximation to geographic reality, as they are filled with popular, symbolic and cultural knowledge (Gorayeb; Meireles; Silva, 2015). For Acselrad et al. (2010), social cartographic products present data on history, culture and technology, and therefore can express and modify ideas about the territory and the relationships established there. The mapping occurs from an alignment of community knowledge with technical knowledge, because the products generated undergo adjustments in order to satisfy cartographical conventions and become official documents

The concept of social cartography as discussed by Acselrad and Coli (2008), Almeida (2013), Gorayeb, Meireles and Silva (2015), creates quali-quantitative information that establishes the participation of individuals in the production of maps of their territories, so that the locations of threats to water, food and energy security are linked to concrete geographic facts. Thus, producing maps for the appropriation of material and symbolic spaces is a political and social strategy for empowerment and autonomy through representation of a local population's knowledge in relation to their space, environment and culture.

Participatory mapping in this study was conducted by applying the SWOT Methodology and the spatialization of the information obtained in the SWOT matrix. SWOT is an acronym for Strengths, Weaknesses, Opportunities, and Threats. This technique, commonly used in the area of business management, is a structural tool capable of understanding the environment, assessing internal and external issues, strengths and weaknesses, threats and opportunities, as well as creating a database needed for planning strategies for future and organizational performance (Helms \& Nixon, 2010).

SWOT methodology is now being applied in different ways, such as participatory socio-environmental diagnoses (Gomide et al., 2015; Saravalle et al., 2016; Xavier; Caetano; Brannstrom, 2020).

For example, Saravalle et al. (2016) used SWOT as one technique for constructing a sustainable development project aimed at a participatory socio-environmental diagnosis. The authors consider SWOT the essential technique in the assessment and participatory characterization of the local reality of the settlement, permitting an exchange between scientific knowledge and popular wisdom.

Gomide et al. (2015) utilized the SWOT matrix as one of the methodological stages for understanding the social interactions and processes of information transmission in a river community in southern Amazonia as a means of aiding basic healthcare strategies. The authors expressed the certainty "that the communication of the results of the social network analysis via the SWOT matrix facilitates understanding and the potential for dissemination by 
means of multipliers in the communities studied" (Gomide et al. 2015, p. 229).

Xavier, Gorayeb and Brannstrom (2020), utilized the SWOT matrix as a participatory diagnostic tool to analyze the introduction of an offshore wind farm project on the west coast of Ceará, together with fishermen from nearby communities, leading to reflections on their way of life.

Thus, the SWOT matrix is a useful participatory methodology for understanding the WEF nexus in traditional communities. The integration of the two participatory methods promoted community reflection and cartographic representation of the elements that compose the nexus in two categories of thematic maps: 1) water, food and energy security maps (Strengths and Opportunities in the matrix) and 2) water, food and energy insecurity maps (Weaknesses and Threats in the matrix).

\section{Methodology}

The quali-quantitative analysis of the WEF nexus used two main tools: (i) a socio-environmental data survey using the SWOT matrix and (ii) spatialization of the SWOT matrix utilizing participatory mapping.

Field data collection was possible because residents agreed to participate in the research activities, the starting point of which were university extension activities conducted at the community school. These activities, together with the awareness of the main community leaders, brought everyone together around the proposal of building the SWOT matrix and local social maps. The researchers knocked on every door in the community, extending personal invitations, hours before the meetings began.

The SWOT matrix was conducted by means of guiding questions. The questions were divided into different axes based on the theoretical claims that guide the assessment of human and sustainable development. Additionally, the guiding questions facilitated the discussions based on the aspects related to the WEF nexus: accessibility, reliability, availability, quality, etc.

In addition to meetings for preparing the SWOT matrix, strategic actions were developed for a university extension course for adults and children containing subject matter on each nexus sector and workshops on income generation, at the request of the community. The extension activities further encouraged trust and the motivation of the residents to construct the SWOT matrix, which propelled the connection to and the participation of the residents in the proposed activities, assuring the quality and validity of the data obtained.

The SWOT matrices were developed during five meetings with the residents of Ponta de Urumajó. The meetings were held in the month of October 2018 and the month of July 2019. All participants were female.

Participatory maps were constructed from the constituent elements in the SWOT matrix and took place in three stages: i) obtain cartographic materials; ii) produce the participatory maps with the community (social cartography workshop); iii) vectorization of the maps and final layout.
The base maps utilized in the social cartography workshop were obtained by Google Earth Pro. After obtaining the satellite images of the community of Ponta do Urumajó, these images were printed in sizes $\mathrm{A} 0$ and $\mathrm{A} 3$, where the image at scale 1:1200 was printed on A0 and the image at scale 1:14000 was printed on A3. The utilization of different scales and sizes of paper was necessary in order to obtain larger and smaller range of area to be mapped.

In addition to these two images of the community of Ponta do Urumajó, satellite images were obtained and printed of Augusto Corrêa, at scale 1:14000 and size A3, as were satellite images of Bragança, at scale 1:20000 and size A3. The images of Augusto Corrêa and Bragança, important localities and a reference for the community, according to the residents, were necessary to attain a broader possibility of locating other points of relevance beyond the limits of the community (e.g., markets for sale of fruit, vegetables, and manioc flour), butchers, COSANPA (Sanitation Company of Pará) and Equatorial Energia Pará, among others).

The materials utilized for the production of the water, food and energy security and insecurity maps were: 6 satellite images of Ponta do Urumajó (scale 1:1200 size A0), 6 satellite images of Ponta do Urumajó (scale 1:14000 size A3), 6 satellite images of the center of Augusto Corrêa (scale 1:14000 size A3) and 6 satellite images of the center of Bragança (scale 1: 20000 size A3), markers of various sizes and colors for the legend, stickers for the legend, office paper, paperclips and stapler.

The multiscale satellite images made it possible to construct social maps from a pre-defined legend with elements from the SWOT matrix. The construction of the social maps visualizing the WEF nexus was made possible by analyzing the multiscale satellite images and the prior selection of the legends, which had the purpose of preconceiving the items that could be represented on the maps, facilitating the spatialization of the elements during the workshops. The map legends, both for the securities and insecurities, were the result of the elements inserted in the SWOT Matrix. The elements contained in Strengths and Opportunities corresponded to the security map legends whereas the elements present in Weaknesses and Threats were part of the water, food, and energy insecurities map legends.

The participatory mapping workshop took place at the Professora Ester Gomes Municipal Lower School at the beginning of the COVID-19 pandemic in Brazil, in March 2020 , with the participation of about 15 people, all women. The exploratory fieldwork also involved photography and location collection by means of GNSS signal receptors, for composition of the final layout of the maps; drawing and painting workshops for the children, held during the map production workshop for the adults; and a soap production workshop focused on environmental education and reutilization of kitchen oil, held after the social map production. These workshops were held together with the social cartography workshop to motivate the participation of the residents in the proposed activities, in addition to 
developing an affective link and closeness to the community

Initially, there was a brief presentation of the satellite images so that the workshop participants could orient themselves in the territory. For the creation of the participatory maps, the techniques of sketching (CORBETT, 2006) and satellite image overlay were used. The participants began by drawing points, lines and polygons of items from the preconceived legends (Figure 2 ). Despite the predefined legend, they were given total freedom to create and construct new items or even to exclude themes, if the participants felt it was pertinent.

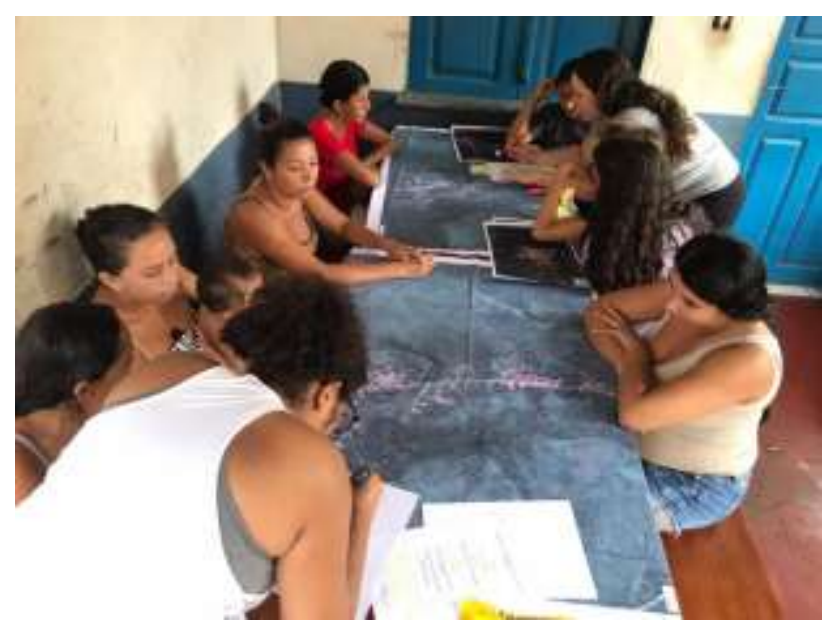

Figure 2. Creation of the Participatory Maps in Ponta do Urumajó, Pará, Brazil

Vectorization of the elements inserted and preparation of the final layout was done in an office setting with free and open Software QGIS 3.10.4. Coordinate System UTM Zone 24 South, Datum Sirgas 2000 was used for georeferencing base maps obtained on the Google Earth Software, for production, vectorization, and finalization of the digital maps. The final maps were validated remotely in March 2021 by people who participated in the workshops, via social networks, especially WhatsApp, due to the social distancing protocols of the COVID-19 pandemic and the impossibility of returning in person to the community.

This paper integrates research at the master's level, procedures were maintained regarding ethics in social research: Certificate of Presentation of Ethical Appreciation - CAAE/ UFC 46462821.0.0000.5054.

\section{Results}

Community residents represented eleven items in the Water Security map legend and eight items on the Water Insecurity map (Table 1). The water tower was represented as a security because it is from where the entire community's water supply comes, being a unique and extremely important element to the residents. Another security represented on the map were the individual wells (Figure 3 ) and the community supply well (at the same place as the water tower), because the residents emphasized that there is no water shortage in these wells. The fishing route and locations, together with the clamming areas, were represented on the security map. They are considered an opportunity that guarantees residents' survival and income generation. The points that do not receive piped water were listed as an insecurity, because residents have unequal access to water.

\begin{tabular}{|c|c|}
\hline $\begin{array}{l}\text { WATER } \\
\text { SECURITY }\end{array}$ & $\begin{array}{l}\text { 1) Areas with piped water; } \\
\text { 2) Homes with individual well; } \\
\text { 3) Leisure area (swimming and } \\
\text { fishing); } \\
\text { 4) Points that should have } \\
\text { environmental awareness; } \\
\text { 5) Fishing boat routes; } \\
\text { 6) Clamming areas; } \\
\text { 7) Boat mooring points; } \\
\text { 8) Location for building a future water } \\
\text { and sewage treatment station, } \\
\text { including an office of the Pará } \\
\text { Sanitation Company (COSANPA); } \\
\text { 9) Fishing points; } \\
\text { 10) Water tower and well for } \\
\text { community supply; } \\
\text { 11) Location for a future Ponta do } \\
\text { Urumajó Residents Association }\end{array}$ \\
\hline $\begin{array}{c}\text { WATER } \\
\text { INSECURITY }\end{array}$ & $\begin{array}{l}\text { 1) Points with no access to piped } \\
\text { water; } \\
\text { 2) Uncovered wells; } \\
\text { 3) Community Water Tower pump; } \\
\text { 4) Points of pollution; } \\
\text { 5) Area with low intensity of piped } \\
\text { water supply; } \\
\text { 6) River silting; } \\
\text { 7) Deforestation area; } \\
\text { 8) COSANPA located in the } \\
\text { municipality of Augusto Corrêa. }\end{array}$ \\
\hline
\end{tabular}

Table 1. Water Security and Insecurity Map Legends.

Another insecurity is related to the water distribution pump. Residents reported a concern with water shortage brought on by interruptions in the motor functioning, because of management or energy problems, laying bare the connection between water and energy insecurity. Issues of pollution and river silting were also represented on the insecurity map, with locations highlighted on the water security map identifying places that require environmental awareness. The COSANPA office located in the municipality of Augusto Corrêa was represented on the insecurity map because residents reported delays in service as well as bad management. Furthermore, the demand for the construction of a future sewage and water treatment station within the community itself was represented on the water security map. 


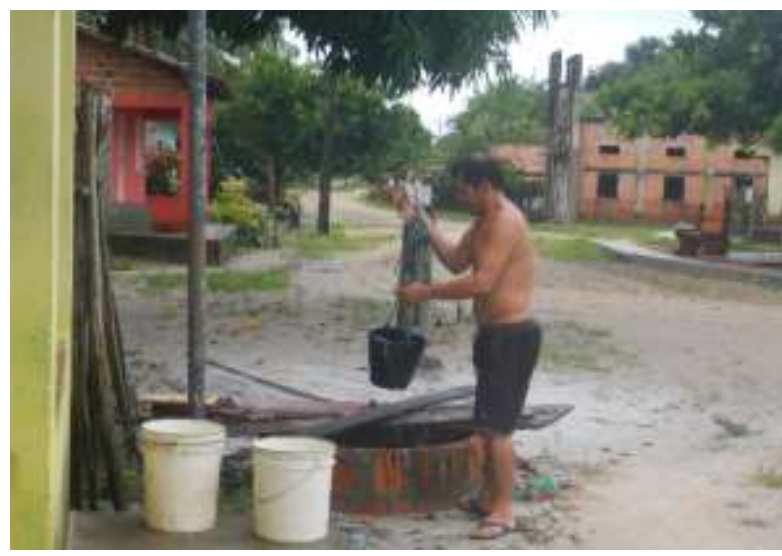

Figure 3. Example of a shallow residential well, common at the local homes.

The community residents represented a total of seventeen items in the on the Food Security map legend and seven items on the Food Insecurity map (Table 2, Figure 4).

\begin{tabular}{|c|c|}
\hline $\begin{array}{c}\text { FOOD } \\
\text { SECURITY }\end{array}$ & $\begin{array}{l}\text { 1) Fishing areas; } \\
\text { 2) Clamming areas; } \\
\text { 3) Flour production; } \\
\text { 4) Sales route (bread, crab, cilantro); } \\
\text { 5) Planting areas; } \\
\text { 6) Home vegetable gardens; } \\
\text { 7) Location set aside for a future } \\
\text { community Garden; } \\
\text { 8) Homes from the Project "My } \\
\text { House My Life"; } \\
\text { 9) Locations for raising animals; } \\
\text { 10) Location for offering courses on } \\
\text { income generation; } \\
\text { 11) Points of sale of homemade ice } \\
\text { cream; } \\
\text { 12) Points of sale of fruits and } \\
\text { vegetables; } \\
\text { 13) Plantation area of Manioc } \\
\text { /Maniva; } \\
\text { 14) Feeding areas for cattle; } \\
\text { 15) Location for construction of } \\
\text { health clinic; } \\
\text { 16) Market locations (sale of fruits, } \\
\text { vegetables and manioc flour); } \\
\text { 17) Butcher locations }\end{array}$ \\
\hline $\begin{array}{c}\text { FOOD } \\
\text { INSECURITY }\end{array}$ & $\begin{array}{l}\text { 1) Location of the Health Clinic of } \\
\text { Perimirim; } \\
\text { 2) Points of pollution; } \\
\text { 3) Route of free-range cattle; } \\
\text { 4) Points of sale of bad quality, } \\
\text { industrialized and canned foods; } \\
\text { 5) Area of minimal bean planting; } \\
\text { 6) Travel to purchase food in Augusto } \\
\text { Corrêa; } \\
\text { 7) Homes without açaizeiros }\end{array}$ \\
\hline
\end{tabular}

Table 2. Food Security and Insecurity map Legends.

Fishing areas, clamming, manioc flour production and animal raising (Figure 5) were also represented within the context of food security because they symbolize the food sovereignty of the region and reinforce the community income, which comes mainly from these sources. The homes from the federal government Project "Minha Casa Minha Vida" ("My House My Life") were represented as an important factor for the residents in the context of food security, because it means they can prioritize spending their income on food rather than on rent, for example. The location for offering income generation courses was seen as an opportunity for the generation of employment, envisioning courses directed at food production within the community. Points of sale of homemade ice cream, fruits and vegetables were represented within the community itself.

Moreover, they reported that, in order to see a doctor, they need to go $4.2 \mathrm{~km}$ to a nearby community, Perimirim. Hence, the location of the Perimirim Health Clinic was included on the food insecurity map.

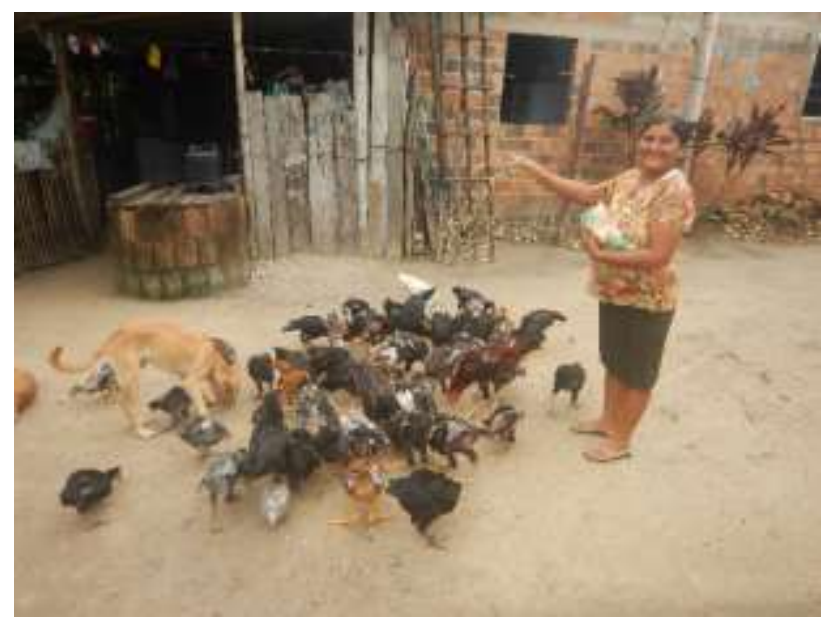

Figure 5. The yard of a home raising small animals for subsistence.

The open market locations, on the other hand, together with butchers, were in the municipalities of Augusto Corrêa and Bragança. The location set aside for the construction of a health clinic was represented due to the nonexistence of doctors and dentists in Ponta do Urumajó. The participants highlighted this as one of the main sectors of opportunity in the food context of the community.

The planting of açai and of manioc for flour production was represented as a source of community income generation. The homes that do not have açaizeiros (açaí palm groves) were inserted in the food insecurity map because of the lack of this source of income. On the other hand, areas of manioc/maniva (ground manioc leaves) plantation were included on the food security map. Travel to purchase food in Augusto Corrêa was represented as an insecurity, because it is a problem that interferes in the obtainment and access to food, negatively affecting their freedom of choice. The free-range cattle route was understood as an issue of food insecurity. Residents reported that this form of husbandry threatens food production. Cattle constantly destroy community residents' plantations. This was one of the most cited elements during the SWOT development activity. 


\section{FOOD SECURITY AND INSECURITY MAP}

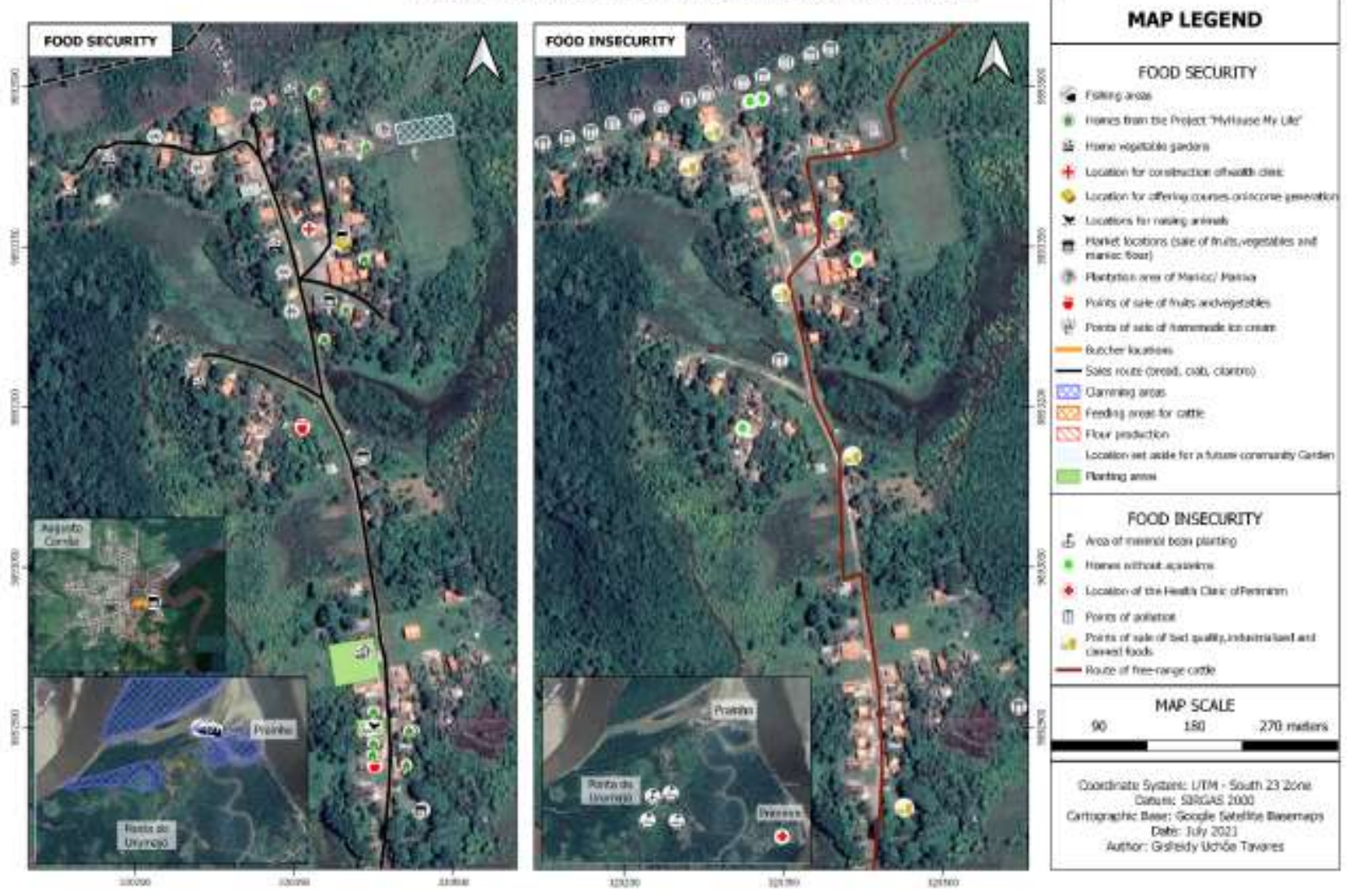

Figure 4. Participatory map of food security and insecurity of Ponta do Urumajó community, Augusto Corrêa, Brazil.

Seven items were included in the Energy Security map legend and eight items were included in the Energy Insecurity map legend (Table 3 ).

One of the main strengths cited was the assurance of electric and thermal energy within the community, represented as energy security the area of electric supply, the area where electric power reaches the community, the points of sale of kitchen gas in the community, and the points of sale of charcoal. The residents included their wish for the installation of a generator and a service office for the Electric Company of Pará (CELPA) and locations that need electric power distribution poles, because they represent improvements to the community's electric grid, improvements in public illumination, and improvements in residential access to electricity. Along the same lines, the residents emphasized locations that lack public illumination on the energy insecurity map, which, according to them, can cause accidents in the community. Energy inspection was included as insecurity, symbolized by areas because, according to the participants, the existence of clandestine connections to the power grid is extremely dangerous. Similarly, they included points were there are iron or aluminum illumination poles (Figure 6), which could also cause accidents, as was the case of an incident included on the insecurity map. Power disruption and outage in the rainy season, the low electrical power and the occurrence of electrical appliance malfunctions, were some of the negative points listed in the SWOT.

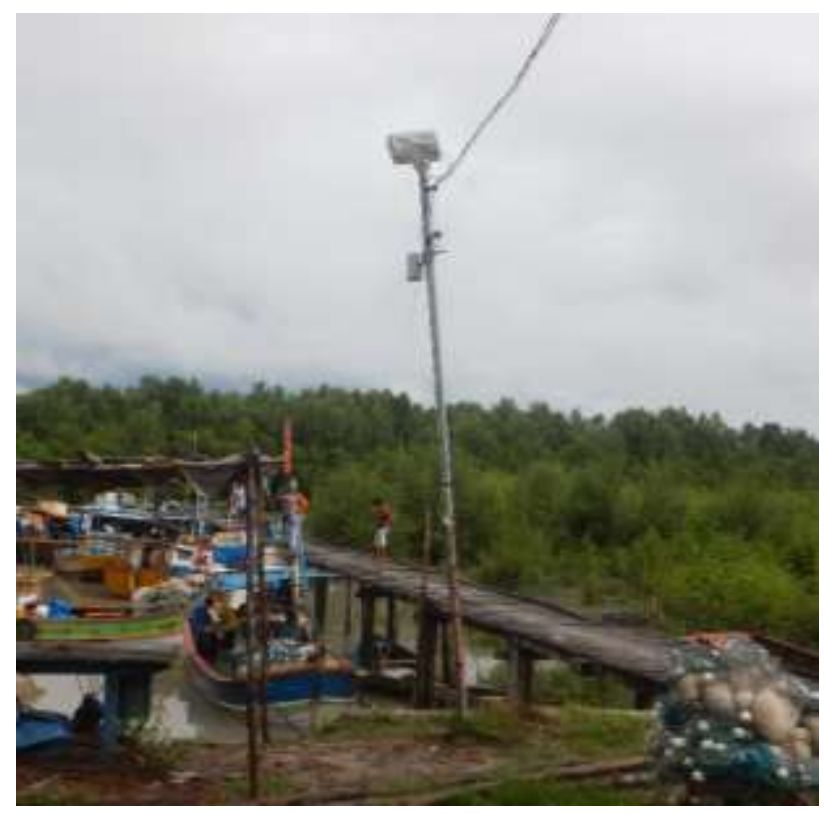

Figure 6. Iron and aluminum illumination poles.

One of the main weaknesses highlighted was related to the lack of power for the water pump to function. This emphasized the threat of water shortage caused by the energy issue, showing the connection between water and energy insecurity. 


\section{Conclusions}

We analyzed the water-food-energy nexus through a bottom-up approach utilizing qualitative methodologies to produce a preliminary understanding of the WEF nexus at the community scale in Ponta do Urumajó, Pará state, Brazil. Two participatory methodologies, the SWOT matrix and participatory mapping, were used in complementary manner. Extension workshops were fundamental to assure data quality and validity.

The interconnections of the nexus sectors are clear in the mapping process and products. Water is interconnected with energy in relation to the energy needs for the functioning of the water supply pump. Energy is interconnected with food in relation to the use of cooking gas, wood, and charcoal for meal preparation. Food is interconnected with water as it is necessary to have good quality water for washing and preparing food or to grow food and raise animals.

Limitations of participatory mapping include highly variable views of territory among participants. Therefore, it is important to associate other methodologies to the participatory mapping, such as the SWOT matrix, with the purpose of complementing the information and overcoming limitations that may arise. Thus, participatory mapping based on the spatialization of the SWOT matrix elements provided the basis for learning the social, environmental, territorial and political reality in terms of the WEF nexus, as well as developing possible strategies to identify and minimize future impacts.

Discussing the WEF nexus in all spheres of society is essential in building awareness about the need to learn more about these resources and the importance of protecting and rethinking their use, contributing as well to the attainment of the Sustainable Development Goals.

\section{Acknowledgements}

We would like to express our gratitude to the residents of the community of Ponta do Urumajó as well as those who helped in some way to build this research project. We also wish to acknowledge $\mathrm{CNPq} / \mathrm{Nexus}$ I Project Proc. $\mathrm{n}^{\circ}$ 441489/2017-6 "Social Technologies and integrated sustainability actions for the assurance of water, energy and food security at a community level in the cearense semiarid region", Universal Project MCTI/CNPq N ${ }^{\circ}$ 01/2016: "Dry periods in the semiarid region and in Eastern Amazonia: influence on aquatic ecosystems, landscapes and vulnerable communities" and PRINT/ CAPES Project Proc. n. 88887.312019/2018-00 "Socioenvironmental technologies and integrated methodologies in territorial sustainability: community alternatives in the face ate changes" for supporting the actions developed during the study.

\section{References}

Acselrad, H.; Coli, L. R. (2008). Disputas territoriais e disputas cartográficas. In H. Acselrad (Ed.), Cartografias sociais e território. (pp. 13-43). Universidade Federal do Rio de Janeiro, Instituto de Pesquisa e Planejamento Urbano e Regional.
Acselrad, H. (2010). Mapeamentos, identidades e territórios. In H. Acselrad (Ed.). Cartografia social e dinâmicas territoriais: marcos para o debate. (pp. 9-46). Universidade Federal do Rio de Janeiro, Instituto de Pesquisa e Planejamento Urbano e Regional.

Almeida, A. W. B. (2013). Nova cartografia social: territorialidades específicas e politização da consciência das fronteiras. In A. W. B. Almeida (Ed.). Povos e Comunidades Tradicionais: nova cartografia social. (pp.157-173) Manaus: PNCSA/UEA

Albrecht, T. R., Crootof, A., \& Scott, C. A. (2018). The Water-Energy-Food Nexus: A systematic review of methods for nexus assessment. Environmental Research Letters, 13(4), 043002

Corbett, J., Rambaldi, G., Kyem, P., Weiner, D., Olson, R., Muchemi, J., McCall, M., \& Chambers, R. (2006). Overview: Mapping for Change - the emergence of a new practice. In G. Rambaldi, J. Corbett, R. O. Mike McCall, J. Muchemi, P. K. Kyem, D. Weiner, \& R. Chambers. (Eds.), Participatory Learning and Action (Issue April, pp. 13-20). International Institute for Environment and Development (IIED).

Dalla Fontana, M., Moreira, F. de A., Di Giulio, G. M., \& Malheiros, T. F. (2020). The water-energy-food nexus research in the Brazilian context: What are we missing? Environmental Science and Policy, 112, 172-180.

Freitas, A. L. R. de, Gorayeb, A., Rocha, B. T. G. da, Mendes, J. de S., \& Pereira, L. C. C. (2017). Aplicação de metodologias participativas na gestão territorial de comunidades ribeirinhas da Amazônia Oriental, Nordeste do Pará. In A. Gorayeb, A. J. de A. Meireles, I. M. C. Lustosa, \& M. G. de Almeida (Eds.), Anais do IV Colóquio Internacional de Turismo em Terras Indígenas e de Comunidades Tradicionais (pp. 129-152). Expressão Gráfica Editora.

Gomide, M., Schütz, G. E., Carvalho, M. A. R. de, \& Câmara, V. de M. (2015). Fortalezas, Oportunidades, Fraquezas e Ameaças (Matriz FOFA) de uma Comunidade Ribeirinha Sul-Amazônica na perspectiva da Análise de Redes Sociais: aportes para a Atenção Básica à Saúde. Cadernos Saúde Coletiva, 23(3), 222230.

Gorayeb, A . Cartografia Social e Populações Vulneráveis. Oficina do Eixo Erradicação da Miséria. Texto e Edição: Eliane Araujo. Laboratório de Geoprocessamento (Labocart) da Universidade Federal do Ceará (UFC). Fevereiro de 2014.

Gorayeb, A., Meireles, A. J. A. \& Silva, E. V. (2015). Princípios Básicos de Cartografia e Construção de Mapas Sociais: metodologias aplicadas ao mapeamento participativo. In A. Gorayeb, A. J. A. Meireles \& E. V. Silva (Ed.). Cartografia Social e Cidadania: experiências de mapeamento participativo dos territórios de comunidades urbanas e tradicionais. (pp. 9-24) Fortaleza, Brazil: Expressäo Gráfica.

Helms, M. M., \& Nixon, J. (2010). Exploring SWOT analysis - where are we now?: A review of academic 
research from the last decade. Journal of Strategy and Management, 3(3), 215-251.

Karlberg, L.; Hoff, H.; Amsalu, T.; Andersson, K.; Binnington, T.; Flores-López, F.; de Bruin, A.; Gebrehiwot, S.G.; Gedif, B.; zur Heide, F.; Johnson, O.; Osbeck, M. and Young, C. (2015). Tackling complexity: Understanding the food-energy-environment nexus in Ethiopia's Lake Tana Sub-basin. Water Alternatives 8(1): 710-734

Kraftl, P., Balastieri, J. A. P., Campos, A. E. M., Coles, B., Hadfield-Hill, S., Horton, J., Soares, P. V., Vilanova, M. R. N., Walker, C., \& Zara, C. (2019). (Re)thinking (re)connection: Young people, "natures" and the waterenergy-food nexus in São Paulo State, Brazil. Transactions of the Institute of British Geographers, 44(2), 299-314.

Leal, R. N., Balestieri, J. A. P., Zara, C., Walker, C., Hall, J., \& Kraftl, P. (2018). (Re)conectando o nexo: percepção e experiências de jovens brasileiros sobre o nexo águaenergia-alimento. Educ. Foco, 23(3), 963-988.

Leck, H., Conway, D., Bradshaw, M., \& Rees, J. (2015). Tracing the Water-Energy-Food Nexus: Description, Theory and Practice. Geography Compass, 9(8), 445460.

Melloni, G., Turetta, A. P. D., Bonatti, M., \& Sieber, S. (2020). A stakeholder analysis for awater-energy-food nexus evaluation in an atlantic forest area: Implications for an integrated assessment and a participatory approach. Water (Switzerland), 12(7), 1977.

Mercure, J. F., Paim, M. A., Bocquillon, P., Lindner, S., Salas, P., Martinelli, P., Berchin, I. I., de Andrade Guerra, J. B. S. O., Derani, C., de Albuquerque Junior, C. L., Ribeiro, J. M. P., Knobloch, F., Pollitt, H., Edwards, N. R., Holden, P. B., Foley, A., Schaphoff, S., Faraco, R. A., \& Vinuales, J. E. (2019). System complexity and policy integration challenges: The Brazilian Energy- WaterFood Nexus. Renewable and Sustainable Energy Reviews, 105, 230-243.

Saravalle, C. Y., Lopes, P. R., Franceschini, G., Freire, L., \& Esquerdo, V. F. de S. (2016). Projeto de desenvolvimento sustentável santa helena - São Carlos/SP: uma problematização das oportunidades, fraquezas, ameaças e fortalezas. Retratos De Assentamentos, 19(1), 99-115.

Saravalle, C. Y., Lopes, P. R., Franceschini, G., Freire, L., \& Esquerdo, V. F. de S. (2016). Projeto de desenvolvimento sustentável santa helena - São Carlos/SP: uma problematização das oportunidades, fraquezas, ameaças e fortalezas. Retratos De Assentamentos.

Xavier, T. W. de F., Gorayeb, A., \& Brannstrom, C. (2021). Parques Eólicos Offshore No Brasil E Os Potenciais Impactos Sociais: Aplicação De Matrizes Swot. Arquivos de Ciências Do Mar, 53(Especial), 8999. 